\title{
Antifungal Activity of Selected Medicinal Plant Extract on Fusarium oxysporum Schlechtthe Causal Agent of Fusarium Wilt Disease in Tomato
}

\author{
Farzana Ashrafi Neela ${ }^{*}$, Ismat Ara Sonia1, Shamim Shamsi ${ }^{2}$ \\ ${ }^{1}$ Department of Botany, Rajshahi University, Rajshahi, Bangladesh \\ ${ }^{2}$ Department of Botany, Dhaka University, Dhaka, Bangladesh \\ Email: ${ }^{*}$ nfarzanaashrafi@yahoo.com
}

Received 7 May 2014; revised 5 July 2014; accepted 5 August 2014

Copyright (C) 2014 by authors and Scientific Research Publishing Inc.

This work is licensed under the Creative Commons Attribution International License (CC BY).

http://creativecommons.org/licenses/by/4.0/

(c) () Open Access

\section{Abstract}

The antifungal activity of ethanol and acetone extract of leaves of nine medicinal plants: Piper betel, Lowsonia inermis, Psidium guajava, Carica papaya, Moringa oleifera, Mimosa pudica, Catharanthus roseus, Adhatoda vasica and Andrographis paniculata against Fusarium oxysporum the causal agent of Fusarium wilt in tomato was assessed. All the extracts inhibited mycellial growth at various levels. Among them the superior inhibition $(100 \%)$ was found in $15 \%$ concentration of ethanol extract of Lowsonia inermis and Psidium guajava against Fusarium. In all plant extract there were no significant differences between $20 \%$ and $25 \%$ concentration, except Piper betel, Carica papaya, Andrographis paniculata and Lawsonia inermis. Analysis of variance results on mycelial growth in different concentration shows that the item was highly significant.

\section{Keywords}

Medicinal Plants, Acetone Extract, Ethanol Extract, Inhibitory Effect, Disease Management

\section{Introduction}

Tomato (Lycopersicon esculentum Mill.) is economically the most important and popular vegetables throughout the world including Bangladesh. Successful cultivation of tomato is hindered by various diseases caused by

${ }^{*}$ Corresponding author.

How to cite this paper: Neela, F.A., Sonia, I.A. and Shamsi, S. (2014) Antifungal Activity of Selected Medicinal Plant Extract on Fusarium oxysporum Schlechtthe Causal Agent of Fusarium Wilt Disease in Tomato. American Journal of Plant Sciences, 5, 2665-2671. http://dx.doi.org/10.4236/ajps.2014.518281 
plant pathogens. Fusarium wilt of tomato caused by Fusarium oxysporum f. sp. lycopersici is one of the most wide spread and destructive diseases, causing infection and losses to crop growers [1]. It is now a major concern not only in Bangladesh, but also in other regions of the world [2].

Use of synthetic fungicides is mainly practiced for management of wilt disease [3]. This measure may cause adverse effects on the environment and human health [4]. In addition the residue of fungicides remaining in the fruit may decrease the quality of the product. The increased awareness of the environmental problems associated with fungicides has led to the search for non-conventional chemicals of biological origin for the management of this disease. Therefore, it is challenge of time to search an alternative control measure of plant diseases by using natural plant materials.

The antimicrobial activity of medicinal plant has been recognized for many years. Leaf extract of Lawsonia inermis, Achyranthes aspera, Mimosa pudica, has been reported significant antimicrobial activities [5] [6]. Plant extract may represent an ideal solution to the problem; it could be easily tested in vitro [7]. The effects of neem products have been reported to have significant controlling effects against fungal spore germination [8]. Extract of Terminalia chebula, Mangifera indica and Eucalyptus citriodora and their essential oils have been reported to be effective antimicrobials against bacteria and fungi [9]. The chloroform extract of Piper betle L. was found to be effective in controlling Fusarium spp. [10] [11]. Aqueous extracts of 46 plants against Fusarium spp. revealed that 12 plants have recorded significant antifungal activity and these plants could be exploited for eco-friendly management [10]. However, the use of plant products for control of Fusarium wilt of tomato in Bangladesh is rather limited. In this study, we reported the effectiveness of ethanol and acetone extract of some common medicinal plants in reducing populations of $F$. oxysporum the causal agent of Fusarium wilt in tomato in vitro.

\section{Materials and Methods}

\subsection{Preparation of Fungal Media (Potato Dextrose Agar)}

The composition of Potato Dextrose is $4 \mathrm{gm} / \mathrm{L}$ of potato extract and $20 \mathrm{gm} / \mathrm{L}$ of dextrose. For solidification 20 $\mathrm{gm} / \mathrm{L}$ of agar was added. Final $\mathrm{pH}$ of this media is $5.6 \pm 0.2$ at $25^{\circ} \mathrm{C}$. These constituents were mixed, autoclaved and poured into Petri plates for solidification. These plates were used for antifungal studies.

\subsection{Isolation and Identification of the Pathogen}

The infected parts of tomato plant were collected in the polythene bags, which were made airtight. Collected materials were labeled properly and then brought to the Laboratory of Plant Pathology, Mycology and Microbiology, Department of Botany, University of Rajshahi, Bangladesh. The pathogen was isolated on potato dextrose agar (PDA) medium [12]. The infected parts of tomato plant were cut into small pieces. The pieces were then washed in running tap water, sterilized in 0.1 percent mercuric chloride solution and washed repeatedly for several times in sterilized distilled water to remove mercuric chloride solution. Three pieces were transferred to PDA plate. Plates were incubated at $25^{\circ} \mathrm{C} \pm 2^{\circ} \mathrm{C}$ for 15 days for recovery of pathogen. Fusarium oxysporum was purified by single spore method and according to morphological characteristics; identification was done with the help of standard keys [13] [14]. Pathogenicity tests were done on potted tomato plants according to Koch's postulate [12].

\subsection{Preparation of Plant Materials}

Fresh leaves of nine medicinal plants were collected from the surrounding areas of Motihar, Rajshahi, Bangladesh (Table 1). Plant specimens were brought to the Laboratory of Plant Pathology, Mycology and Microbiology, Department of Botany, University of Rajshahi. These plants were authenticated by Taxonomist Dr. A. H. M. Mahbubur Rahman, Associate Professor, Department of Botany, University of Rajshahi, and a voucher specimen was deposited at the Herbarium of the Department.

Leaves of plants were washed thoroughly under running tap water and soaked in $2 \%$ solution of sodium hypochlorite for $20 \mathrm{~min}$, rinsed thoroughly with sterilized distilled water and air dried at room temperature. The dried plant materials were milled. $100 \mathrm{~g}$ of each finely ground plant materials were used for extraction in $100 \mathrm{ml}$ of ethanol and acetone solvents, respectively. The solution was kept overnight at room temperature and filtered using filter papers (Whatman filter paper No. 1). 
Table 1. List of plant materials used in this study.

\begin{tabular}{ccc}
\hline Local name & Scientific name & Family \\
\hline Pan & Piper betel L. & Liliaceae \\
Mehedi & Lowsonia inermis L. & Lythraceae \\
Payara & Psidium guajava L. & Myrtaceae \\
Pepe & Carica papaya L. & Caricaceae \\
Sojina & Moringa oleifera Lam. & Moringaceae \\
Lojjaboty & Mimosa pudica L. & Fabaceae \\
Nayontara & Catharanthus roseus (L.) G Don & Aacanthaceae \\
Basok & Adhatoda vasica L. & Aacanthaceae \\
Kalomegh & Andrographis paniculata (Burm.f.) & Aacanthaceae \\
& Wall. Ex Nees & \\
\hline
\end{tabular}

\subsection{Effect of Different Concentrations of Extracts on Radial Growth of Fusarium Strain}

Plant extracts which could suppress the fungal growth were tested for their efficiency against the pathogen by using an agar dilution technique. Five ml of each extract concentration was added with 95 ml of molten PDA. Thus obtained concentration of 5\%, 10\%, 15\%, 20\% and 25\% extract to a PDA medium. After the solidification of the medium, $1 \mathrm{~cm}$ diameter of mycelia block from 7-day-old colony of $F$. oxysporum was inoculated in the center of each Petri plate and incubated at $\pm 25^{\circ} \mathrm{C}$. The colony diameter of $F$. oxysporum was measured after 7 days of incubation. Three replicates in a completely randomized design were used within each treatment. The media amended with ethanol and acetone was considered as negative and recommended fungicide sulcox was considered as positive control, respectively. The efficacy of medicinal plant products was expressed and percent of radial mycelial growth over the control which was calculated by using the following formula [7]:

$$
\text { Inhibition }(\%)=[(\mathrm{C}-\mathrm{T}) / \mathrm{C}] \times 100
$$

where, $\mathrm{C}$ and $\mathrm{T}$ represent the diameter of control and treated colony, respectively. Data on mycelial growth at 3 , 6, 9 and 12 days after inoculation (DAI) were recorded. To avoid bacterial contamination 0.5 g of antibacterial streptomycin was added to $1 \mathrm{~L}$ of PDA medium.

\subsection{Statistical Analysis}

The effect of ethanol and acetone extract of plants at different concentrations on the radial growth of $F$. oxysporum evaluated by a one way analysis of variance (ANOVA). Mean differences between treatments or concentration levels of the plant extracts were separated by Fisher's [15] test significant difference (LSD) at 5\% significant probability level. The ANOVA was computation by R programming language.

\section{Result and Discussion}

For eco-friendly and sustainable management of Fusarium wilt disease, the present study tested the antifungal activity of ethanol and acetone extracts and their respective dilutions of nine selected medicinal plants based on their availability in Rajshahi and their traditional use against fungal pathogen. It was found that at 25\% concentration; almost all plant extracts were effective in reducing the mycelial growth of Fusarium strain (Table 2). Effect of different plant extracts on radial mycelial growth of Fusarium sp. on 12 days of incubation (DAI) is presented in Table 3 and Table 4. Hundred percent inhibition at 12 DAI and 25\% concentration were observed on almost all plant extract except ethanol extract of Andrographis paniculata (91\%), Carica papaya (89.41\%), Moringa oleifera (90.59\%) and on acetone extract of Andrographis paniculata (85\%), Catharanthus roseus (90.76\%) and Psidium guajava (87.5\%). Maximum inhibition was found at 15\% concentration of ethanol extract of Lowsonia inermis and Psidium guajava against studied fungi. Representative figure was showed in Figure 1. Plant extract of Piper betel, Carica papaya, Andrographis paniculata and Lawsonia inermis did not show significant difference between $20 \%$ and $25 \%$ concentrations. Result of analysis of variance on mycelial growth in different concentration showed that the item was highly significant. LSD value also indicates significant in different concentrations of plant extract and radial growth (Table 3 and Table 4). 
Table 2. Effect of different plant extracts in two solvents at $25 \%$ concentration on growth of Fusarium sp.

\begin{tabular}{ccc}
\hline Plant material & \multicolumn{2}{c}{$\%$ of inhibition } \\
\hline P. betel & 100 & Acetone \\
\hline L. inermis & 100 & 100 \\
P. guajava & 100 & 100 \\
C. papaya & 89.41 & 87.5 \\
M. oleifera & 90.59 & 100 \\
C. roseus & 100 & 100 \\
M. pudica & 100 & 90.76 \\
A. vasica & 100 & 100 \\
A. paniculata & 91 & 100 \\
& & 85 \\
\hline
\end{tabular}

Table 3. Effect of various concentration of ethanol extracts on the radial mycelial growth (average mm) on Fusarium sp. at 12 DAI.

\begin{tabular}{|c|c|c|c|c|c|c|}
\hline \multicolumn{7}{|c|}{ Cconcentration of ethanol extract } \\
\hline Plant material & $5 \%$ & $10 \%$ & $15 \%$ & $20 \%$ & $25 \%$ & LSD \\
\hline P. betel & $30 a^{*}$ & $14.76 \mathrm{~b}$ & $12.33 \mathrm{c}$ & od & od & 2.101 \\
\hline L. inermis & $6.67 \mathrm{a}$ & $6 b$ & 0c & 0c & 0c & 0.469 \\
\hline P. guajava & $39.67 a$ & $9.33 b$ & 0c & 0c & 0c & 1.558 \\
\hline C. papaya & $48.67 a$ & $32.33 b$ & $18.33 \mathrm{c}$ & $15.67 d$ & 8.33e & 1.758 \\
\hline M. oleifera & 34.33a & $17.67 \mathrm{~b}$ & $11.67 \mathrm{c}$ & $7.67 d$ & $7.67 d$ & 1.937 \\
\hline C. roseus & 43.33a & $14.67 b$ & $6 c$ & od & Od & 1.558 \\
\hline M. pudica & 37.33a & $15.33 b$ & $10.33 c$ & Od & Od & 1.819 \\
\hline A. vasica & $41 \mathrm{a}$ & $6 b$ & $6 b$ & 0c & 0c & 1.409 \\
\hline A. paniculata & $26.67 a$ & $18.67 \mathrm{~b}$ & $10 \mathrm{c}$ & $9.67 \mathrm{~cd}$ & 8.33d & 1.485 \\
\hline
\end{tabular}

*Each treatment was replicated 3 times means followed by the same letter within a row do not differ significantly at $\mathrm{p}>0.05$ according to LSD test by $\mathrm{R}$ programming language.

Table 4. Effect of various concentration of acetone extracts on the radial mycelial growth (average mm) on Fusarium sp. at 12 DAI.

\begin{tabular}{ccccccc}
\hline & \multicolumn{7}{c}{ Concentration of acetone extract } \\
\hline Plant material & $\mathbf{5 \%}$ & $\mathbf{1 0 \%}$ & $\mathbf{1 5 \%}$ & $\mathbf{2 0 \%}$ & $\mathbf{2 5 \%}$ & LSD \\
\hline P. betel & $23.67 \mathrm{a}^{*}$ & $9.67 \mathrm{~b}$ & $6 \mathrm{c}$ & $0 \mathrm{~d}$ & $0 \mathrm{~d}$ & 2.253 \\
L. inermis & $18 \mathrm{a}$ & $6 \mathrm{~b}$ & $6 \mathrm{~b}$ & $0 \mathrm{c}$ & $0 \mathrm{c}$ & 0.814 \\
P. guajava & $28 \mathrm{a}$ & $22.33 \mathrm{~b}$ & $16 \mathrm{c}$ & $11 \mathrm{~d}$ & $8.67 \mathrm{e}$ & 1.558 \\
C. papaya & $36.33 \mathrm{a}$ & $20.33 \mathrm{~b}$ & $6 \mathrm{c}$ & $0 \mathrm{~d}$ & $0 \mathrm{~d}$ & 1.329 \\
M. oleifera & $18.33 \mathrm{a}$ & $13.33 \mathrm{~b}$ & $8.33 \mathrm{c}$ & $6 \mathrm{~d}$ & $0 \mathrm{e}$ & 1.993 \\
C. roseus & $42.33 \mathrm{a}$ & $33 \mathrm{~b}$ & $29.67 \mathrm{c}$ & $17.67 \mathrm{~d}$ & $6 \mathrm{e}$ & 1.993 \\
M. pudica & $16.33 \mathrm{a}$ & $8.67 \mathrm{~b}$ & $8.33 \mathrm{~b}$ & $6.33 \mathrm{c}$ & $0 \mathrm{~d}$ & 1.243 \\
A. vasica & $35.33 \mathrm{a}$ & $18.33 \mathrm{~b}$ & $6 \mathrm{c}$ & $6 \mathrm{c}$ & $0 \mathrm{~d}$ & 2.395 \\
A. paniculata & $30.33 \mathrm{a}$ & $24.67 \mathrm{~b}$ & $17.33 \mathrm{c}$ & $14.33 \mathrm{c}$ & 14 & 3.845 \\
\hline
\end{tabular}

*Each treatment was replicated 3 times means followed by the same letter within a row do not differ significantly at $\mathrm{p}>0.05$ according to LSD test by $\mathrm{R}$ programming language. 


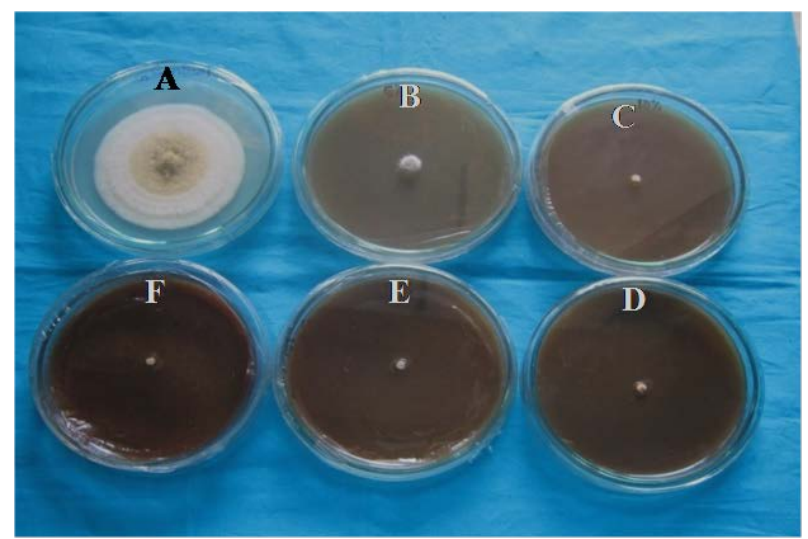

Figure 1. Superior inhibition of ethanol extract of Psidium guajava against Fusarium strain. Control (A); 5\% (B); 10\% (C); 15\% (D); $20 \%$ (E) and 25\% (F) of concentration.

From the investigation, it was observed that leaf extract of Piper betel in ethanol and acetone at 20\% concentrations effectively suppressed the mycelial growth of the F. oxysporum. Inhibition observed by $P$. betel may be due to the presence of the essential oils which contained phenolic compounds [16] [17]. There have been reports on the antifungal activities of $P$. betle [18]. Singha et al. [11] reported the control of fusarium wilt of tomato caused by Fusarium oxysporum using chloroform extract of $P$. betle leaf. They observed that it was efficient in reducing Fusarium population in soil than carbendazim. These facts suggested that betel leaf extracts exhibit significant fungicidal properties that inhibit the mycelia growth of Fusarium strain.

The inhibitory effect of leaf of Lawsonia inermis was effective in 15\% ethanol than acetone solution at 12 DAI. It is not surprising because Lawsonia inermis Linn. or henna has been used since the earliest times as a herbal medicine. Antifungal activity study with different concentrations of ethyl acetate and ethanol extract of flower and leaf of Lawsonia inermis was dose dependent and was found to be effective even at $1 \mathrm{mg} / 100 \mu \mathrm{l}$ against Penicillium notatum, Fusarium oxysporum, Colletotrichum gloeosporioides except Rhizopus stolonifer [19]. The fungicidal property of $L$. inermis might be due to the presence of Lawsone 2-hydroxyl-1, 4-Naphthaquino [20].

The ethanol extract of Psidium guajava and acetone extract of Carica papaya displayed inhibitory activities, respectively. Few reports are available on these plants for developing commercial formulations for applications against fungal pathogen. Previous study demonstrated that the acetone extracts of leaves of above plants showed moderate to strong activity against Aspergillus niger, Fusarium sp. and Candida albicans [21], whereas we have found that the ethanol extract of $P$. guajava showed strong inhibition at $15 \%$ concentration and acetone extract of C. papaya were at $20 \%$ concentration against Fusarium sp., respectively. The results indicated that the two plant extracts are good antifungal agents but $P$. guajava is more effective than C. papaya. It is therefore, encouraging to identify and characterize the active principle of these two plants.

Moringa oleifera is an exceptionally nutritious vegetable tree with a variety of potential uses [22]. The plant was reported to contain various amino acids, fatty acids, vitamins, and nutrients [22]. The seed oil has physical and chemical properties equivalent to that of olive oil and contains a large quantity of tocopherols [23]. Many reports described the antifungal and antibacterial activities of $M$. oleifera [24]. Ethanol extracts of $M$. oleifera seeds and leaves showed anti-fungal activities in vitro against dermatophytes. Furthermore, 44 chemical compounds were found in essential oil from leaves of $M$. oleifera [25]. The fruit extract of M. oleifera showed a broad-spectrum antifungal activity against Colletotrichum, Curvularia, Fusarium and Alternaria at different concentrations of methanol extract [22]. In this investigation, we have also found the antifungal activity of $M$. oleifera leaves was effective against Fusarium sp. at 25\% concentration of acetone than ethanol solvent. This result is noteworthy because this extracts showed a positive relationship with the other findings.

Catharanthus roseus is well known for its pharmacological significance [26]. Antifungal potential in crude extracts of C. roseus against clinically significant fungal strains (Candida albicans, Aspergillus fumigatus, Aspergillus niger, Fusarium moniliforme) has been reported and ethanol solvent was found to be better extraction solvent as compared to acetone [26]. In this study, we have also found that ethanol extracts of leaf of C. roseus 
were more effective than acetone extract and reduced the mycelia growth of $F$. oxysporum. It showed $100 \%$ inhibition of the test fungus at $20 \%$ ethanol solution. These data depicts that the pattern of inhibition largely depend upon extraction solvent.

Ethanol and acetone leaf extract of Mimosa pudica and Adhatoda vasica at 25\% concentration 100\% inhibition were recorded. Methanolic extract of $M$. pudica exhibited least activity against Pithyum debaryanum [27]. Siva et al. [28] reported that ethanol and acetone leaves extract of Adhatoda vasica showed $100 \%$ inhibition against $F$. oxysporuim at $40 \%$ concentration. Present result showed that ethanol and acetone leaf extract of $M$. pudica and A. vasica were more effective than the observation of Ambikapathy et al. [27] and Siva et al. [28].

Radial mycelial growth was recorded at all concentration of leaf extract of Andrographis paniculata. The lowest radial mycelial growth was measured in $25 \%$ concentration of leaf extract of A. paniculata at 12 DAI $8.33 \mathrm{~mm}$ in ethanol as solvent and $14 \mathrm{~mm}$ in acetone extract. Yasmin et al. [29] was first reported on antifungal properties of leaf extract of A. paniculata resulted 33.53\% growth inhibition of Fusarium moniliforme. Present study also supported the findings of Yasmin et al. [29] that A. paniculatamay serve as candidates of plant species for their exploitation as potent fungitoxicants for controlling Fusarium wilt of tomato.

\section{Conclusion}

In conclusion, the present study laboratory screening of plant extracts has given encouraging results, indicating their potential use in the management of Fusarium wilt in tomato caused by Fusarium oxysporum. Further field trial and photochemical analysis of the active compounds of those plants would give a strong antifungal activity comparable to synthetic fungicides. The plant materials used in this study are abundant and commonly found in Rajshahi, Bangladesh.

\section{Acknowledgements}

The authors are thankful to the Department of Botany, Rajshahi University, Bangladesh for providing the necessary facilities.

\section{References}

[1] Hanaa, R.M.F., Abdou, Z.A., Salama, D.A., Ibrahim, A.R. and Sror, H.A.M. (2011) Effect of Neem and Willow Aqueous Extracts on Fusarium Wilt Disease in Tomato Seedlings: Induction of Antioxidant Defensive Enzymes. Annals of Agricultural Sciences, 56, 1-7. http://dx.doi.org/10.1016/j.aoas.2011.05.007

[2] Agbenin, N.O. and Marley, P.S. (2006) In-Vitro Assay of Some Plant Extracts against Fusarium oxysporum f. sp. lycopersici Causal Agent of Tomato. Journal of Plant Protection Research, 46, 117-121.

[3] Akkopru, A. and Demir, S. (2005) Biological Control of Fusarium Wilt in Tomato Caused by Fusarium oxysporum f. sp. lycopersici by AMF Glomus intraradices and Some Rhizobacteria. Journal of Phytopathology, 153, 544-550. http://dx.doi.org/10.1111/j.1439-0434.2005.01018.x

[4] Agbenin, N.O., Emechebe, A.M. and Marley, P.S. (2004) Evaluation of Neem Seed Powder for Fusarium Wilt and Meloidogne Control on Tomato. Archives of Phytopthology and Plant Protection, 37, 319-326. http://dx.doi.org/10.1080/03235400412331273359

[5] Aktar, A., Neela, F.A., Khan, M.S.I., Islam, M.S. and Alam, M.F. (2010) Screening of Ethanol, Petroleum Ether and Chloroform Extracts of Medicinal Plants Lawsonia inermis L. and Mimosa pudica L. for Antibacterial Activity. Indian Journal of Pharmaceuticals Science, 72, 388-392.

[6] Khan, M.S.I., Neela, F.A., Aktar, A., Rahman, M.M. and Alam, M.F (2009) Antibacterial Activity of Achyranthes aspera L.-An in Vitro Study. Journal of Environmental Science \& Natural Resources, 2, 45-48.

[7] Dissanayake, M.L.M.C. (2014) Inhibitory Effect of Selected Medicinal Plant Extracts on Phytopathogenic Fungus Fusarium oxysporum. Annual Research \& Review in Biology, 4, 133-142. http://dx.doi.org/10.9734/ARRB/2014/5777

[8] Singh, U.P., Singh, H.B. and Singh, R.B. (1980) The Fungicidal Effect of Neem (A. indica) Extracts on Some Soil Born Pathogens of Gram (Cicer arietinum). Mycologia, 72, 1077-1093. http://dx.doi.org/10.2307/3759561

[9] Parekh, J. and Chanda, S. (2006) Screening of Aqueous and Alcoholic Extracts of Some Indian Medicinal Plants for Antibacterial Activity. Indian Journal of Pharmceutical Sciences, 68, 835-838. http://dx.doi.org/10.4103/0250-474X.31032

[10] Satish, S., Raghavendra, M.P. and Raveesha, K.A. (2009) Anti-Fungal Potentiality of Some Plant Extracts against Fusarium spp. Archives of Phytopathology and Plant Protection, 42, 618-625. 
http://dx.doi.org/10.1080/03235400701287578

[11] Singha, I.M., Kalita, M.C., Wann, S.B., Kakoty, Y., Das, J., et al. (2011) Control of Fusarium wilt of Tomato Caused by Fusarium oxysporum f. sp. lycopersici Using Leaf Extract of Piper betle L.: A Preliminary Study. World Journal of Microbiology and Biotechnology, 27, 2583-2589. http://dx.doi.org/10.1007/s11274-011-0730-6

[12] Agrios, G. (2005) Plant Pathology. 5th Edition, Elsevier Academic Press, Amsterdam, 26-27,398-401.

[13] Booth, C. (1971) The Genus Fusarium. Commonwealth Mycological Institute, Kew, Surrey, 237.

[14] Nelson, P.E., Toussoun, T.A. and Marasas, W.F.O. (1983) Fusarium Species. In: An Illustrated Manual for Identification, Pennsylvania State University Press, University Park, 193.

[15] Fisher, A., Immer, F.R., and Tedin, O. (1932) The Genetical Interpretation of Statistic of the Third Degree of Study of Quantitative Inheritance. Genetics, 17, 107-114.

[16] Phangthip, P., Thaewnonngiw, B., Kanchanarach, W., Sangdee, A. and Rittideth, S. (2005) Antifungal Efficacy of Piper betle Linn. Extract against the Growth of Mat Fungi. 31st Congress on Science and Technology of Thailand, Bangkok, 18-20 October 2005, 3.

[17] Begum, J., Yusuf, M., Chowdhury, J.U., Khan, S. and Nural, A.M. (2007) Antifungal Activity of Forty Higher Plants against Phytopathogenic Fungi. Bangladesh Journal of Microbiology, 24, 76-78.

[18] Ali, I., Khan, F.G., Suri, K.A., Gupta, B.D., Satti, N.K., Dutt, P., et al. (2010) In Vitro Antifungal Activity of Hydroxychavicol Isolated from Piper betle L. Annals of Clinical Microbiology and Antimicrobials, 9, 7-15. http://dx.doi.org/10.1186/1476-0711-9-7

[19] Jeyaseelan, E.C., Vinuja, T., Pathmanathan, K. and Jeyadevan, J.P. (2012) Control of Plant Pathogenic Fungi Using Organic Solvent Extracts of Leaf, Flower and Fruit of Lowson iainermis L. International Journal of Pharmaceutical and Biological Archives, 3, 783-788.

[20] Themnozhi, M. and Sivaraj, R. (2009) Phytochemical Analysis of Antimicrobial Activity of Polyalthia longifolia. International Journal of Pharma and Bio Sciences, 1, 1-7.

[21] Karsha, P.V., Naseem, S. and Bhagyalakshmi, O. (2009) Antimicrobial Activity of Leaf Extracts of Guava (Psidium guajava) and Papaya (Carica papaya). Advances in Plant Sciences, 22, 429-431.

[22] Sayeed, M.A., Hossain, M.S., Chowdhury, M.E.H. and Haque, M. (2012) In Vitro Antimicrobial Activity of Methanolic Extract of Moringa oleifera Lam. Fruits. Journal of Pharmacognosy and Phytochemistry, 1, 94-96.

[23] Tsaknis, J., Lalas, S., Gergis, V., Dourtoglou, V. and Spilotis, V. (1999) Characterisation of Moringa oleifera Variety Mbololo Seed Oil of Kenya. Journal of Agricultural and Food Chemistry, 47, 4495-4499. http://dx.doi.org/10.1021/jf9904214

[24] Gupta, R., Kannan, G.M., Sharma, M. and Flora, S.J.S. (2005) Therapeutic Effects of Moringa oleifera on Arsenic Induced Toxicity in Rats. Environmental Toxicology and Pharmacology, 20, 456-464. http://dx.doi.org/10.1016/j.etap.2005.05.005

[25] Chuang, P.H., Lee, C.W., Chou, J.Y., Murugan, M., Shieh, B.J. and Chen, H.M. (2007) Anti-Fungal Activity of Crude Extracts and Essential Oil of Moringa oleifera Lam. Bioresource Technology, 98, 232-236. http://dx.doi.org/10.1016/j.biortech.2005.11.003

[26] Kratika, K. and Gupta, S. (2013) Antifungal Properties of Leaf Extract of Catharanthus roseus L. (G.) Don. American Journal of Phytomedicine and Clinical Therapeutics, 1, 698-705.

[27] Ambikapathy, V., Gomathi, S. and Panneerselvam, A. (2011) Effect of Antifungal Activity of Some Medicinal Plants against Pythium debaryanum (Hesse). Asian Journal of Plant Science and Research, 1, 131-134.

[28] Siva N., Ganesan, S. and Muthuchelian, B.N. (2008) Antifungal Effect of Leaf Extract of Some Medicinal Plants against Fusarium oxysporum Causing Wilt Disease of Solanum melogena L. Ethnobotanical Leaflets, 12, 156-163.

[29] Yasmin M., Hossain, K.S. and Bashar, M.A. (2008) Effects of Some Angiospermic Plant Extracts on in Vitro Vegetative Growth of Fusarium moniliforme. Bangladesh Journal of Botany, 37, 85-88. 
Scientific Research Publishing (SCIRP) is one of the largest Open Access journal publishers. It is currently publishing more than 200 open access, online, peer-reviewed journals covering a wide range of academic disciplines. SCIRP serves the worldwide academic communities and contributes to the progress and application of science with its publication.

Other selected journals from SCIRP are listed as below. Submit your manuscript to us via either submit@scirp.org or Online Submission Portal.
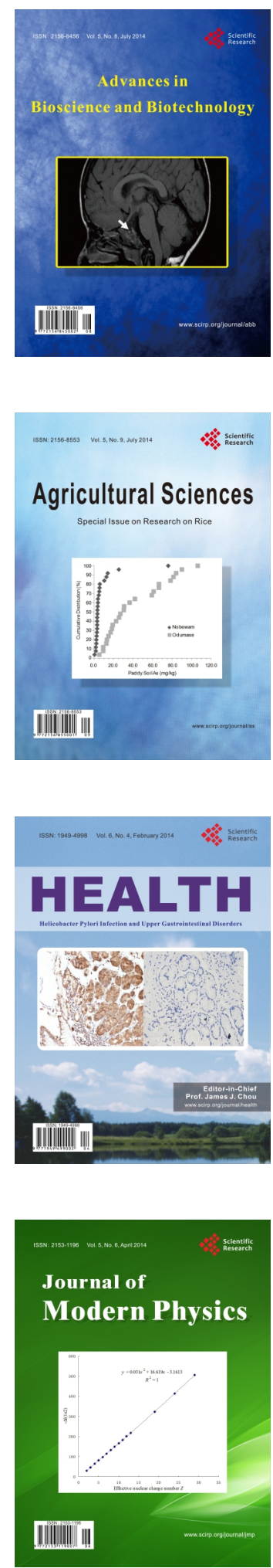
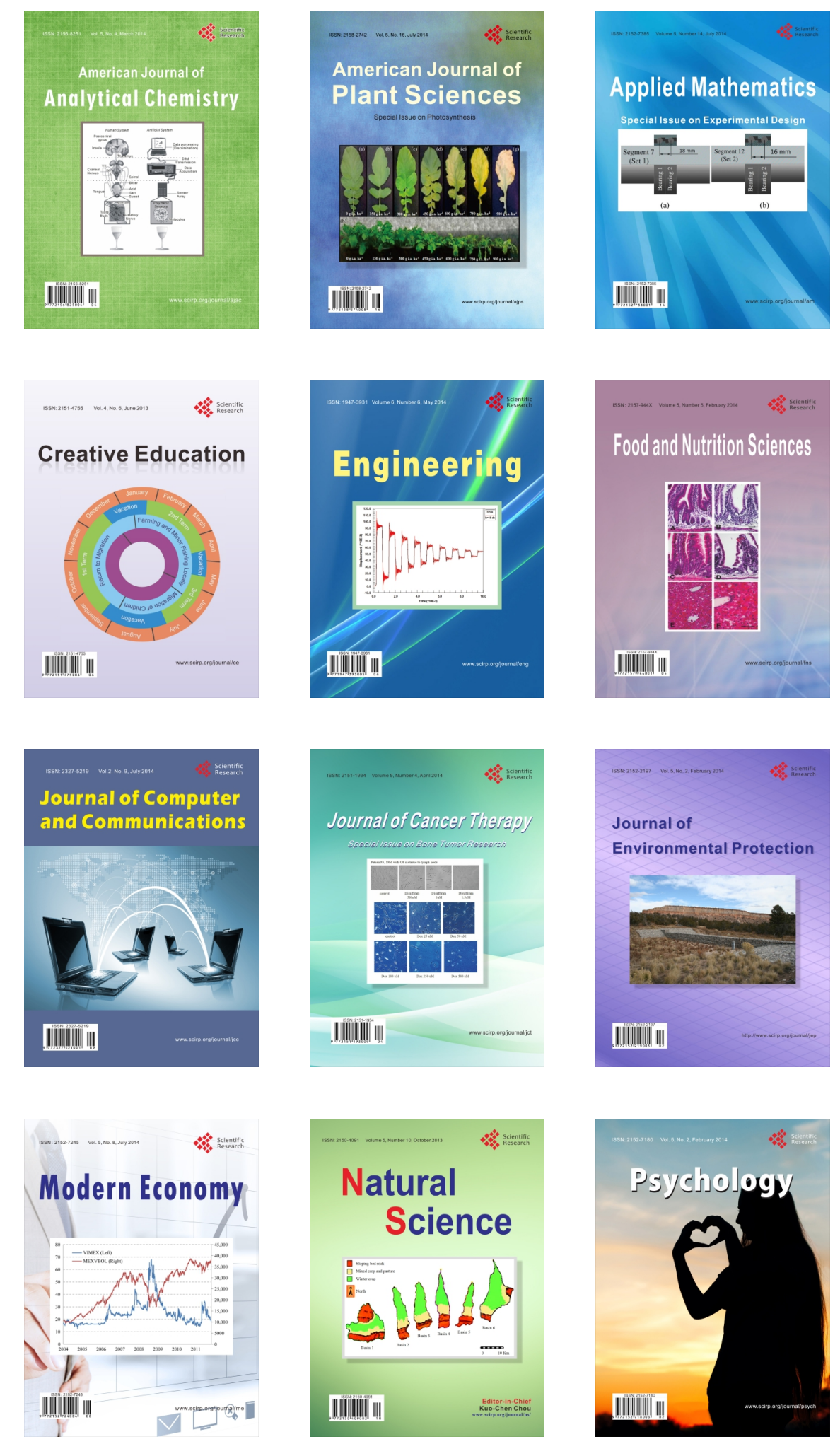